\title{
Nurses' competencies in health promotion for homebound older people
}

\author{
Competências do enfermeiro para promoção da saúde de idosos no domicílio \\ Competencias del enfermero en torno a la promoción de la salud de ancianos en domicilio
}

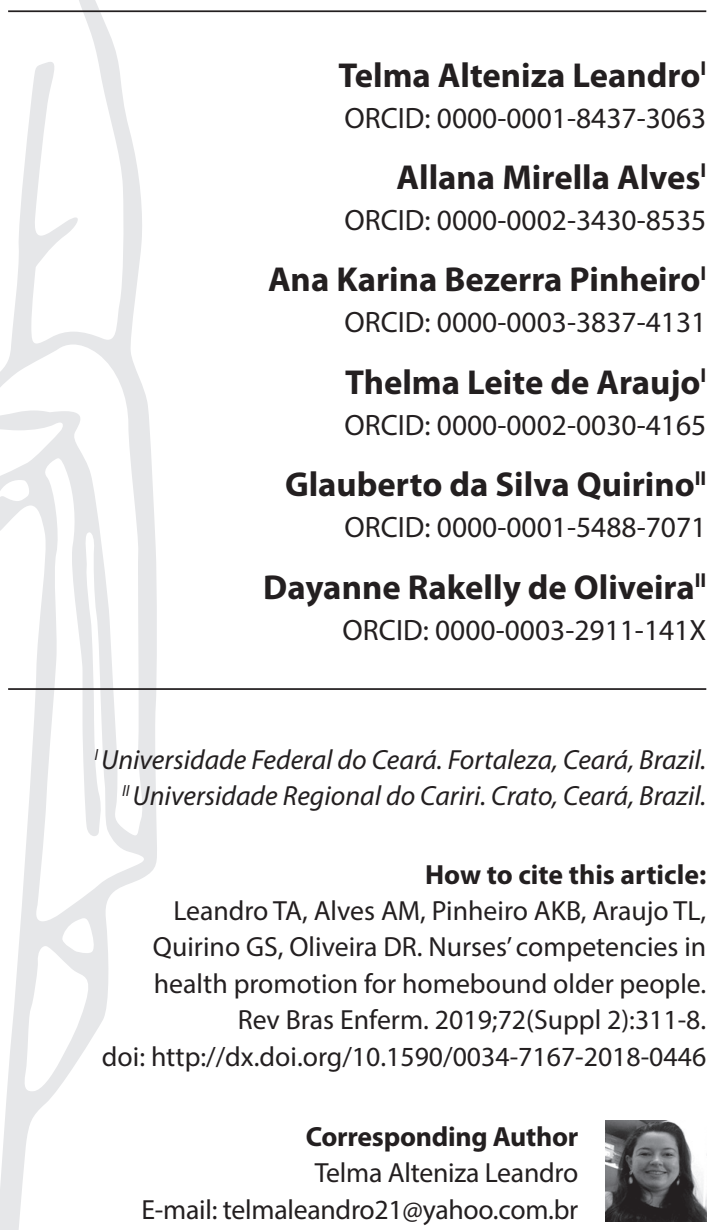

Submission: 06-11-2018 Approval: 07-27-2018

\begin{abstract}
Objective: to identify competencies related to health promotion targeting homebound older people, as they appear in the literature. Method: systematic review using the LILACS, Scopus, CINAHL, PubMed and Cochrane Library databases. The search was performed in November 2017. Selected articles were analyzed according to nine competency domains: enable change; advocate for health; mediate through partnership; communication; leadership; assessment; planning; implementation, and evaluation and research. Results: nine clinical trials were included. All health promotion competency domains were identified in the reviewed research interventions, performed with homebound older people. Conclusion: studies showed that the employed treatments were beneficial for the homebound older population. Interventions based on health promotion competencies were positively identified, and are linked to an effective and high-quality health care practice. Descriptors: Aged; Homebound Persons; Professional Competence; Nursing; Health Promotion.
\end{abstract}

\section{RESUMO}

Objetivo: identificar na literatura as competências do enfermeiro relacionadas à promoção da saúde de idosos no domicílio. Método: revisão sistemática realizada nas bases de dados LILACS, Scopus, CINAHL, no portal PubMed e na biblioteca Cochrane, em novembro de 2017. Os artigos selecionados foram analisados de acordo com os nove domínios de competências: permitir a mudança; advogado para a saúde; mediar através de parceria; comunicação; liderança; avaliação; planejamento; implementação; e avaliação e pesquisa. Resultados: foram incluídos nove ensaios clínicos. Todos os domínios de competências de promoção da saúde foram identificados nas intervenções realizadas nas pesquisas nos idosos residentes no domicílio. Conclusão: os estudos mostraram que os tratamentos utilizados foram benéficos para a população de idosos no domicílio e as intervenções baseadas em competências para a promoção da saúde podem ser identificadas e produzem uma prática assistencial eficaz e de qualidade. Descritores: Idoso; Pacientes Domiciliares; Competência Profissional; Enfermagem; Promoção da Saúde.

\section{RESUMEN}

Objetivo: identificar en la literatura las competencias del enfermero relacionadas a la promoción de la salud de ancianos en domicilio. Método: revisión sistemática realizada en las bases de datos LILACS, Scopus, CINAHL, portal PubMed y biblioteca Cochrane, en noviembre de 2017. Se hizo el análisis de los artículos seleccionados a partir de nueve dominios de competencias: permitir el cambio; preservar la salud; intermediar mediante asociación; comunicarse; liderar; evaluar; planificar; aplicar; y evaluar e investigar. Resultados: se incluyeron nueve ensayos clínicos. Se identificaron todos los dominios de las competencias en torno a la promoción de la salud en las intervenciones realizadas en las encuestas con los ancianos residentes en domicilio. Conclusión: los estudios demostraron que los tratamientos utilizados fueron beneficiosos para la población de ancianos en domicilio, y que las intervenciones con base en las competencias para promover la salud pueden ser identificadas, además de establecer una práctica asistencial eficaz y de calidad.

Descriptores: Anciano; Personas Imposibilitadas; Competencia Profesional; Enfermería; Promoción de la Salud. 


\section{INTRODUCTION}

Recent decades have seen a clear-cut, worldwide phenomenon of population aging. The increase in the number of older people is an expression of improved living conditions, a process comprised of various aspects and directly related to the advancement of health care science ${ }^{(1-2)}$.

In Brazil, health reform has contributed to population aging by broadening the concept of health, which is currently understood not only as the absence of disease but, above all, a result of the conditions underlying social and health care indicators. Among these indicators and their underlying conditions, one should mention the reduction of infant mortality due to the success of government programs directed at children and mothers, the control of chronic-degenerative diseases, and the reduction of birth rates as a result of women's foray into the labor market. All are directly implicated in the population aging phenomenon ${ }^{(3-4)}$.

Estimates show that, in 2010, the Brazilian population reached $190,755,799$ inhabitants. Among these, approximately 21 million, or $11 \%$, were older people ${ }^{(5-6)}$.

The aging Brazilian population is supported by the National Elderly Health Policy, which has the primary purpose of recovering, maintaining and promoting older people's autonomy and independence by directing collective and individual health measures, in line with the principles and guidelines of the Unified Health System. The policy considers the need to improve the quality of care provided to this population, carrying out actions derived from the health promotion paradigm ${ }^{(7)}$.

It is known that this age group has several idiosyncrasies and is vulnerable to multiple physiological risks, mainly related to the loss of bodily functions. This predisposes older people to illness and hospitalization. Providing specific care to the older population means focusing on mitigating weaknesses, maintaining functional capacity, preserving autonomy and minimizing dependence. Thus, actions to promote health in older people have the beneficial effect of maintaining and improving quality of life.

Health promotion programs targeting older people have visible and demonstrable health benefits, effectively contributing to healthy aging. These actions also benefit society as a whole, since they stimulate older people to maintain a healthy lifestyle for a longer period of time, restricting public health spending ${ }^{(8)}$.

The National Elderly Health Policy establishes the expansion of actions for health promotion and education, with the goal of preventing or delaying the appearance of diseases and frailties, and helping older people maintain their independence and autonomy. This expansion should ensure the well-being of the entire older population, promoting health and quality of life ${ }^{(9)}$.

Given the complexity of older people care, a health assistance based on comprehensiveness and interdisciplinarity is essential. Providing health care means more than avoiding diseases: it is also about ensuring an environment able to increase quality of life, i.e., people's autonomy and well-being ${ }^{(10)}$. From this point of view, in order for care targeting homebound older people to be effective, nurses must develop specific competencies.

The CompHP manual was developed in 2012, in Europe, precisely to establish a competencies framework (together with a certification system for health promotion). $\mathrm{It}^{(11)}$ includes nine domains, all pertinent for the development of health care competencies and abilities: enable change; advocate for health; mediate through partnership; communication; leadership; assessment; planning; implementation, and evaluation and research ${ }^{(12)}$.

The analysis of clinical studies contemplating nurses' interventions in the older population has an important role, since their practice in this context is connected to real patient needs. Moreover, in order to be effective, their interventions must be supported by the aforementioned health promotion competencies.

With the above said, we believe this study may provide knowledge on nursing care practices in the promotion of health for homebound older people, by contributing to the characterization of home care work processes. Besides, the identification of the competencies employed in the studied interventions may help improve nursing professionals' current competent practices.

\section{OBJECTIVE}

To identify nurses' competencies as they relate to health promotion actions targeting homebound older people.

\section{METHOD}

\section{Ethical aspects}

As a systematic review, this study was not evaluated by the university's Research Ethics Committee. Included articles were openly accessible to higher education institutions.

\section{Study design}

This was a systematic review of the literature comprised of the following stages: elaboration of research question; database search; article selection; data extraction; methodological quality assessment; data synthesis; evidence quality assessment; writing, and publication of results ${ }^{(13)}$. Article selection followed the recommendations of the Preferred Reporting Items for Systematic Review and Meta-Analysis (PRISMA) (Figure 1). Only clinical trials which provided an answer to the research question, and had the participation of nurses, were included.

\section{Inclusion and exclusion criteria}

To be included, articles had to be available in full. No publication date limit was set. Literature reviews (integrative, conceptual and systematic) as well as qualitative studies were excluded.

\section{Study protocol}

To guide the formulation of this review study's research question, the PVO (Population, Variables and Outcomes) search strategy was employed. $P$ refers to the target population (homebound older people); $V$ to the study variable (professional competence); and $\mathrm{O}$ to interventions' outcomes (health promotion). This led to the formulation of the following research question: what health promotion competencies do nursing professionals demonstrate in interventions performed among homebound older people? 


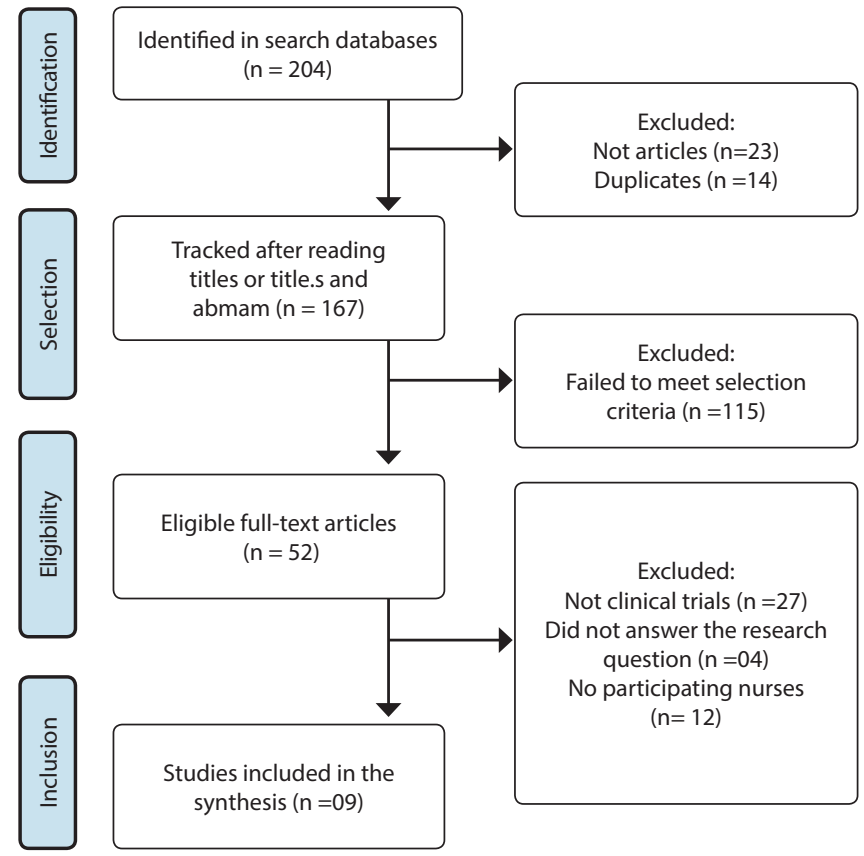

Figure 1 - Strategy for the search and inclusion of articles, following PRISMA recommendations, 2017

The search was conducted in November 2017, using the following databases: Latin American and Caribbean Center on Health Sciences Information (LILACS), Scopus, Cumulative Index to Nursing and Allied Health Literature (CINAHL), National Library of Medicine (PubMed), and Cochrane Library. The following controlled descriptors were used:"nursing", "aged" and "homebound persons," as found in the Descritores em Ciências da Saúde (DeCS) and Medical Subject Headings (MeSH) websites. For the LILACS database, the corresponding descriptors in Portuguese were used.
As a search strategy, the following combination was used in each database/portal:"nursing" AND"aged"AND"homebound persons."

\section{Analysis of results}

After final sample selection, in order to extract information from the included articles, the data were collected by applying a specific instrument, constructed on the basis of certain recommendations ${ }^{(14)}$. The information collected using the instrument was organized into the results presented below.

The data were presented in the form of tables and analyzed according to CompHP's health promotion competencies ${ }^{(11)}$.

\section{RESULTS}

The analyzed studies were developed in the following countries: United States, Norway, Japan and Denmark. The United States had the highest scientific production on the subject (66.7\%). These articles were published between 1999 and 2015, in medical journals (44.5\%), multidisciplinary journals (33.3\%), and nursing journals (22.2\%). In regards to specialization, articles concerned gerontology, geriatrics, ostomies, incontinence, and rehabilitation.

The number of participants in the included studies ranged from 16 to 4034 . The types of interventions performed by the nurses and identified in the studies were quite varied. There were interventions targeting specific health problems of older people (urinary incontinence and depression), as well as more comprehensive interventions dealing with general care and health education.

Data on the analysed scientific articles is presented below (Chart 1). It is worth noting that all competency domains were present in the interventions discussed by the included clinical research studies (Chart 2).

Chart 1 - Synthesis of articles describing interventions performed by nurses among homebound older people, according to author, date of publication, place of study, participants, intervention, and outcome, 2017

\begin{tabular}{|c|c|c|c|}
\hline $\begin{array}{l}\text { Reference and } \\
\text { place of study }\end{array}$ & Design/number of participants & Intervention & Outcome \\
\hline $\begin{array}{l}\text { Tuntland et al. }{ }^{(15)} \text {, } \\
2015 \\
\text { Norway }\end{array}$ & $\begin{array}{l}\text { - } \quad \begin{array}{l}\text { Sixty-one older people with } \\
\text { functional capacity decline. }\end{array} \\
\text { CG: } 30(49.2 \%) \\
\text { IG: } 31(50.8 \%)\end{array}$ & $\begin{array}{l}\text { CG: Conventional care (assistance, patient } \\
\text { safety alarm, meals, assistive technology } \\
\text { and rehabilitation with therapists). } \\
\text { IG: Multicomponent rehabilitation } \\
\text { (identification of limitations imposed } \\
\text { on important activities, supervision of } \\
\text { caregivers, training for daily activities, } \\
\text { environmental adaptations, and exercise } \\
\text { programs). }\end{array}$ & $\begin{array}{l}\text { Significant mean-score improvements } \\
\text { in occupational performance, favoring } \\
\text { rehabilitation. There were no significant } \\
\text { differences between the groups in any } \\
\text { of the secondary outcomes after } 3 \text { or } 9 \\
\text { months; however, both groups improved } \\
\text { in regards to mobility and balance, as } \\
\text { well as most health-related quality of life } \\
\text { domains. These effects were sustained in } \\
\text { the 9-month follow-up. }\end{array}$ \\
\hline $\begin{array}{l}\text { Gellis, Kenaley, } \\
\text { Have }^{(16)}, 2014 \\
\text { United States }\end{array}$ & $\begin{array}{l}\text { Ninety-four clinically frail } \\
\text { elderly individuals } \geq 65 \\
\text { years old with a history of } \\
\text { hospitalization in the last } \\
6 \text { months, or who needed } \\
\text { home care visits } \geq 3 \text { times } \\
\text { per week; all were positively } \\
\text { screened for depression. } \\
\text { CG: } 46(48.9 \%) \\
\text { IG: } 48(51.1 \%)\end{array}$ & $\begin{array}{l}\text { CG: Habitual care provided by home } \\
\text { nurses via home visits and psychotherapy. } \\
\text { IG: Integrated telehealth intervention } \\
\text { consisting of telemonitoring, chronic } \\
\text { disease management, and treatment for } \\
\text { depression. }\end{array}$ & $\begin{array}{l}\text { The groups had marked symptoms of } \\
\text { depression. At } 3 \text { months, the integrated } \\
\text { telehealth group exhibited less depression } \\
\text { than the CG, and the trend continued at } 6 \\
\text { months. At } 3 \text { and } 6 \text { months, no significant } \\
\text { physical health status differences were } \\
\text { found when comparing both groups. } \\
\text { Scores at } 3 \text { months suggest that the IG } \\
\text { exhibited greater problem-solving skills. }\end{array}$ \\
\hline
\end{tabular}




\begin{tabular}{|c|c|c|c|}
\hline $\begin{array}{l}\text { Reference and } \\
\text { place of study }\end{array}$ & Design/number of participants & Intervention & Outcome \\
\hline $\begin{array}{l}\text { Kono et al. }{ }^{(17)}, \\
2013 \\
\text { Japan }\end{array}$ & $\begin{array}{l}\text { - } \quad \text { Three hundred and } \\
\text { seven participants aged } \\
\geq 65 \text { years, homebound, } \\
\text { supported by health } \\
\text { insurance. } \\
\text { CG: } 153(49.8 \%) \\
\text { IG: } 154(50.2 \%)\end{array}$ & $\begin{array}{l}\text { CG: Frail elderly, accompanied at } \\
\text { outpatient clinics. } \\
\text { IG: Frail elderly, accompanied at } \\
\text { outpatient clinics, who had received home } \\
\text { visits from nurses. }\end{array}$ & $\begin{array}{l}\text { The average costs of health care during } \\
\text { the study's 2-year period decreased } \\
\text { slightly in the group who had received } \\
\text { home visits as compared to the CG, but } \\
\text { the difference was not significant. For } \\
\text { most months, financial costs in the IG } \\
\text { were lower than in the CG; considering } \\
\text { the 2-year period, both groups had } \\
\text { similar average costs of hospital care. } \\
\text { Hospitalizations were less likely to occur } \\
\text { in the IG. }\end{array}$ \\
\hline $\begin{array}{l}\text { Gellis et al. }{ }^{(18)} \\
2012 \\
\text { United States }\end{array}$ & $\begin{array}{l}\text { A hundred and two older } \\
\text { people } \geq 65 \text { years of age, } \\
\text { suffering from CHF or COPD, } \\
\text { who were hospitalized at } \\
\text { least twice in the last } 6 \\
\text { months, or who visited the } \\
\text { emergency room at least } \\
\text { twice in the last } 2 \text { months. } \\
\text { CG: } 51(50 \%) \\
\text { IG: } 51(50 \%)\end{array}$ & $\begin{array}{l}\text { CG: Conventional home care and health } \\
\text { education. } \\
\text { IG: Telehealth intervention; monitoring } \\
\text { system in which patients were made } \\
\text { aware of normal clinical parameters } \\
\text { and instructed on when to contact the } \\
\text { health nurse. The nurse was available to } \\
\text { the patient daily, able to be contacted } \\
\text { via telephone, and also able to perform } \\
\text { urgent home visits whenever needed. }\end{array}$ & $\begin{array}{l}\text { At } 3 \text { months, IG patients' scores for } \\
\text { symptoms of depression improved } \\
\text { significantly when compared to the } \\
\text { CG. The telehealth group experienced } \\
\text { significantly greater increases in two of } \\
\text { the three SF-36 scales (general health and } \\
\text { social functioning). The satisfaction with } \\
\text { care survey showed that both groups were } \\
\text { satisfied with their care, without significant } \\
\text { differences. The CG had significantly more } \\
\text { visits to the emergency room than the IG. }\end{array}$ \\
\hline $\begin{array}{l}\text { Shearer, Fleury, } \\
\text { Belyea }^{(19)}, 2010 \\
\text { United States }\end{array}$ & $\begin{array}{l}\text { Forty-two individuals aged } \\
\geq 60 \text { years, who spoke } \\
\text { and understood English, } \\
\text { had good hearing and } \\
\text { well-preserved cognitive } \\
\text { functions. } \\
\text { CG: } 22(52.4 \%) \\
\text { IG: } 20(47.6 \%)\end{array}$ & $\begin{array}{l}\text { CG: Weekly bulletins were sent out to the } \\
\text { CG, providing information on home safety, } \\
\text { medication safety, aging and skin care, } \\
\text { aging and vision, dental care, and bone } \\
\text { health. } \\
\text { IG: Health empowerment intervention } \\
\text { based on six integrated components } \\
\text { (personal resources and building self- } \\
\text { capacity; building self-capacity through } \\
\text { the recognition of one's strengths, self- } \\
\text { talk, purpose in life, personal growth, and } \\
\text { self-acceptance; recognizing and building } \\
\text { social networks; identifying and building } \\
\text { social service utilization; communicating } \\
\text { to build social networks and access social } \\
\text { service providers; and reviewing goals for } \\
\text { the future). The intervention was carried } \\
\text { out during home visits by a trained nurse. }\end{array}$ & $\begin{array}{l}\text { At the } 6 \text { th and } 12 \text { th weeks, the IG } \\
\text { presented a significantly higher goal } \\
\text { achievement score. According to the } \\
\text { employed theoretical framework, there } \\
\text { was no significant main effect on health } \\
\text { empowerment. However, the personal } \\
\text { growth subscale had a significant increase } \\
\text { when comparing the beginning of the } \\
\text { intervention and the } 12 \text {-week point. All in } \\
\text { all, the IG showed more personal growth } \\
\text { than the CG. In the well-being scale, there } \\
\text { were no significant main effect differences } \\
\text { among groups. However, there were } \\
\text { significant differences among the oldest } \\
\text { participants, with a well-being increase in } \\
\text { the IG taking place between the } 6 \text {-week } \\
\text { and the } 12 \text {-week points. There was no } \\
\text { main effect over the total score of the scale } \\
\text { from: evaluating feelings about awareness, } \\
\text { choices, freedom to act intentionally, } \\
\text { and involvement in creating change. } \\
\text { However, men in the IG showed significant } \\
\text { differences in this regard. }\end{array}$ \\
\hline $\begin{array}{l}\text { 20. Boyd et al. }{ }^{(20)} \\
, 2008 \\
\text { United States }\end{array}$ & $\begin{array}{l}\text { - } 150 \text { older people with } \\
\text { high-risk chronic diseases. } \\
\text { High-risk patients are those } \\
\text { most likely to need health } \\
\text { services. } \\
\text { CG: } 63(76 \%) \\
\text { IG: } 31(41 \%)\end{array}$ & $\begin{array}{l}\text { CG: Received usual health care. } \\
\text { IG: Received guided health care. }\end{array}$ & $\begin{array}{l}\text { In comparison to the CG, the IG showed } \\
\text { a tendency of improved quality of } \\
\text { communication between patient } \\
\text { and professional, as well as a more } \\
\text { comprehensive knowledge. There were } \\
\text { no differences for integration of care, } \\
\text { interpersonal treatment, and trust in } \\
\text { physician. }\end{array}$ \\
\hline $\begin{array}{l}\text { Vass et al. }{ }^{(21)} \\
2009 \\
\text { Denmark }\end{array}$ & $\begin{array}{l}\text { - } \begin{array}{l}\text { Four thousand and } \\
\text { thirty-four older people, } \\
\text { home-dwelling, aged } 75 \text { or } \\
80 \text { years. }\end{array} \\
\text { CG: } 1942(48.1 \%) \\
\text { IG: } 2092(51.9 \%)\end{array}$ & $\begin{array}{l}\text { CG: The population belonging to the } \\
\text { control municipalities received usual care. } \\
\text { Professionals from these municipalities did } \\
\text { not participate in any training. } \\
\text { IG: The population belonging to } \\
\text { intervention municipalities was assisted } \\
\text { by professionals who had received } \\
\text { educational training. }\end{array}$ & $\begin{array}{l}\text { Intervention was not associated with } \\
\text { mortality in both groups. During } 4 \text { and } \\
\text { a half years of follow-up, } 6375 \text {-year olds } \\
\text { from the intervention municipalities } \\
\text { moved to nursing homes, compared to } \\
62 \text { in the control municipalities. Among } \\
80 \text {-year olds, } 38 \text { moved to nursing } \\
\text { homes in the intervention municipalities, } \\
\text { as compared to } 48 \text { in the control } \\
\text { municipalities. The hospitalization rates } \\
\text { were lower in the } 80 \text {-year-old participants } \\
\text { of the intervention municipalities. Three } \\
\text { years of intervention improved functional } \\
\text { capacity in } 80 \text {-year-old participants. }\end{array}$ \\
\hline
\end{tabular}




\begin{tabular}{|c|c|c|c|}
\hline $\begin{array}{l}\text { Reference and } \\
\text { place of study }\end{array}$ & Design/number of participants & Intervention & Outcome \\
\hline $\begin{array}{l}\text { Engberg et al. }{ }^{(22)} \\
, 2002 \\
\text { United States }\end{array}$ & $\begin{array}{l}\text { - } \\
\text { Sixteen homebound } \\
\text { individuals aged } \geq 60 \text { years, } \\
\text { suffering from at least } \\
\text { two urinary incontinence } \\
\text { episodes per week } \\
\text { persisting for at least } 3 \\
\text { months. They had cognitive } \\
\text { impairment and were } \\
\text { assisted by caregivers. } \\
\text { CG: } 10(62.5 \%) \\
\text { IG: } 6(37.5 \%)\end{array}$ & $\begin{array}{l}\text { CG: Received visits from nurses to improve } \\
\text { urination control. Subjects and their } \\
\text { caregivers were aware that they were in } \\
\text { a study examining the effectiveness of a } \\
\text { Ul program, but there was no discussion } \\
\text { of incontinence or its treatment with the } \\
\text { caregiver or subject during the nurse's visits. } \\
\text { IG:The treatment consisted of nurse- } \\
\text { oriented behavioral therapy and scheduled } \\
\text { urination performed with the help of } \\
\text { caregivers, for } 8 \text { weeks. There were no } \\
\text { interventions during the night. }\end{array}$ & $\begin{array}{l}\text { There was a mean reduction of } 50 \% \text { in } \\
\text { daytime incontinence episodes compared } \\
\text { to } 37 \% \text { in the control group. The average } \\
\text { daily percentage of wet diapers or } \\
\text { underwear fell by } 43 \% \text {, compared to } 35 \% \\
\text { in the control group. Treated patients } \\
\text { had a } 55 \% \text { decrease in all episodes of } \\
\text { incontinence (day and night) compared to } \\
27 \% \text { in the control group. }\end{array}$ \\
\hline $\begin{array}{l}\text { McDowell et } \\
\text { al. }^{(23)}, 1999 \\
\text { United States }\end{array}$ & $\begin{array}{l}\text { - A hundred and five } \\
\text { cognitively intact, home- } \\
\text { dwelling individuals aged } \\
\geq 60 \text { years, reporting at } \\
\text { least two urinary losses per } \\
\text { week persisting for at least } \\
3 \text { months. } \\
\text { CG: } 52(49.5 \%) \\
\text { IG: } 53(50.5 \%)\end{array}$ & $\begin{array}{l}\text { CG: Nurse visits to provide social } \\
\text { interaction without specifications for UI } \\
\text { treatment, aiming to evaluate the effects of } \\
\text { socialization. Bladder diaries were not filled } \\
\text { during control. Each visit had } 35 \text { minutes. } \\
\text { Visits were carried out for } 8 \text { weeks. } \\
\text { IG: Biofeedback-assisted pelvic floor muscle } \\
\text { exercises, urge and stress strategies, and } \\
\text { bladder retraining. The bladder diary } \\
\text { was assessed weekly, and treatment was } \\
\text { adjusted based on the patient's evolution. } \\
\text { Forty to sixty-minute visits, for } 8 \text { weeks. }\end{array}$ & $\begin{array}{l}\text { The mean number of incontinence } \\
\text { episodes per day decreased from } 4.1 \text { to } 3.5 \\
\text { in the CG. In the IG, it decreased from } 4.0 \\
\text { to } 1.8 \text {. Thus, treated subjects presented a } \\
\text { significant reduction of urinary losses per } \\
\text { day }(P \leq 1) \text {. }\end{array}$ \\
\hline
\end{tabular}

Note: CG: control group; IG: intervention group; Ul: urinary incontinence; CHF: congestive heart failure; COPD: chronic obstructive pulmonary diseas.

Chart 2 - Distribution of articles according to competency domains and nursing interventions, 2017

\begin{tabular}{|c|c|}
\hline $\begin{array}{l}\text { CompHP } \\
\text { domains }\end{array}$ & Nursing interventions \\
\hline Enable Change & $\begin{array}{l}\text { Promote empowerment }{ }^{(15-16,18-19,22-23)} \\
\text { Promote health education }{ }^{(18)} \\
\text { Facilitate the development of skills }{ }^{(18,23)} \\
\text { Professional training }\end{array}$ \\
\hline $\begin{array}{l}\text { Advocate for } \\
\text { Health }\end{array}$ & $\begin{array}{l}\text { Improve health }{ }^{(23)} \\
\text { Enable therapeutic adherence }{ }^{(23)} \\
\text { Facilitate access to community assets } \\
\text { Enable cost reduction }^{(17)} \\
\text { Influence stakeholders for change } \mathrm{e}^{(19,21,23)} \\
\text { Raise awareness on health issues }{ }^{(19)} \\
\text { Stimulus for the use of social resources }{ }^{(19)}\end{array}$ \\
\hline $\begin{array}{l}\text { Mediate } \\
\text { through } \\
\text { Partnership }\end{array}$ & $\begin{array}{l}\text { Partnership with older people and } \\
\text { caregivers }^{(15,17,19,22-23)} \\
\text { Collaborative working }^{(20)} \\
\text { Partnership with the community }{ }^{(20)} \\
\text { Partnership with other professionals }{ }^{(15,21)} \\
\text { Partnership with municipalities and } \\
\text { administrators }\end{array}$ \\
\hline Communication & $\begin{array}{l}\text { Visits at home }{ }^{(16-19,21-23)} \\
\text { Written recommendations and illustrated } \\
\text { material|(15,17,19,21,23) } \\
\text { Use of information technology }{ }^{(20)} \\
\text { Communication instruments (telephone, tape } \\
\text { recorder }^{(16,19-20)} \\
\text { Motivational interview } \\
\text { Use of telehealth technology } \\
\text { Meetings }^{(16,21)}\end{array}$ \\
\hline Leadership & $\begin{array}{l}\text { Incorporate new knowledge } \mathrm{e}^{(21-23)} \\
\text { Supervision and training }{ }^{(15-16,18)} \\
\text { Encourage participants to make changes }{ }^{(15)} \\
\text { Facilitate empowerment and participation }{ }^{(21)}\end{array}$ \\
\hline
\end{tabular}

\begin{tabular}{|c|c|}
\hline $\begin{array}{l}\text { CompHP } \\
\text { domains }\end{array}$ & Nursing interventions \\
\hline Assessment & $\begin{array}{l}\text { Identify existing limitations } \\
\text { Identifying the health needs of patients } s^{(18,20)} \\
\text { Identify priorities for health promotion actions } s^{(15-16,20)} \\
\text { Multidimensional and individualized evaluation }{ }^{(16-17)} \\
\text { Daily assessment of patient data }{ }^{(18,22)}\end{array}$ \\
\hline Planning & $\begin{array}{l}\text { Develop a feasible action plan }{ }^{(15-16,18,23)} \\
\text { Schedule actions } \text { s }^{(17,22)}\end{array}$ \\
\hline Implementation & 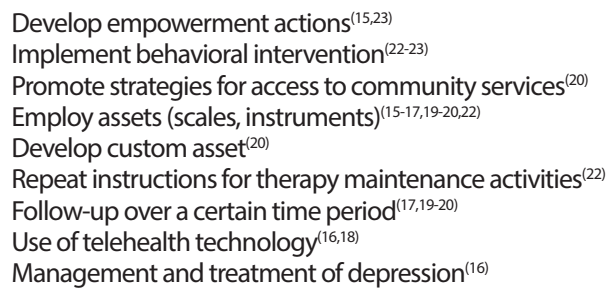 \\
\hline $\begin{array}{l}\text { Evaluation and } \\
\text { Research }\end{array}$ & $\begin{array}{l}\text { Evaluate interventions' results }{ }^{(15-23)} \\
\text { Reassessment of participants at end of treatment }{ }^{(22)}\end{array}$ \\
\hline
\end{tabular}

\section{DISCUSSION}

Most older people present some type of functional difficulty due to the inherent changes of aging ${ }^{(3)}$, justifying the studies analyzed here. It is also known that, in order to maintain their health, this population needs adequate family support, leading the Ministry of Health to recommend older people's permanence in the household. Thus, home care by health professionals is an important health factor ${ }^{(24)}$.

As an important collaborator in the process of improving older people's health, the nurse can and should act as a qualified health professional, applying specific forms of care ${ }^{(15-16,18,21-23)}$. Given the effectiveness of the analyzed nursing interventions, it is clearly 
essential for homebound older people to receive a care approach supported by health promotion competencies. This practice ensures a higher quality of care.

In most of the clinical trials analyzed, the chosen intervention strategies were directed to rehabilitation. In these, the following competencies for health promotion were identified: enable change; advocate for health; mediate through partnership; communication; leadership; assessment; planning; implementation; and evaluation and research. In addition, the authors have identified several professional competency domains necessary for primary health care, such as: communication; assessment; technical abilities; health promotion; management of diseases; health care and information technologies; ethics; health systems and policies; provision of care; and planning ${ }^{(25)}$.

"Mediate through partnership" was one of the most frequently found competencies in nurses' interventions. Its success requires collaborative work involving other health professionals, family members and patients. In this sense, it is worth noting that the involvement of caregivers in the interventions makes treatments more effective. In addition, a successful partnership with caregivers may involve several strategies. The development of skills for guided care and to aid in individualized programs requires the formation of bonds of trust between nursing professionals and caregivers ${ }^{(17,22)}$.

Professionals from several different areas can contribute to health promotion actions. In the studies, physiotherapists, occupational therapists, social educators, physicians, nutritionists and nursing assistants were identified, and worked collaboratively to implement the interventions ${ }^{(15-16,18,21)}$.

Finally, the partnership of health professionals with older people themselves is considered essential, since they are the focus of health interventions. When establishing a partnership with the patient, the practitioner realizes that people cannot take full responsibility for their health unless they are aware of all the options available to them ${ }^{(26)}$. From the perspective of individual attention, health empowerment interventions facilitate the participant's involvement in the process of identifying the desired personal, social and health resources ${ }^{(19)}$.

Empowerment can promote changes that contribute to improving people's health. Enabling these changes helps individuals, groups, communities and organizations to develop capacity for action aimed at improving health and reducing inequalities ${ }^{(11)}$. Nurses are able to bring about changes in older people's lives by promoting education and teaching behavioral therapies for urinary incontinence ${ }^{(22-23)}$, guided care ${ }^{(20)}$, and skills acquisition ${ }^{(18)}$.

Acting for change and facilitating participatory work is a characteristic of leadership ${ }^{(11)}$. In respect to this competency, nursing is considered the health profession most suited to leading and implementing innovative health promotion programs ${ }^{(27)}$. Reflections of leadership can be seen when nurses qualify the health team to act $^{(28)}$, manage and coordinate treatment projects ${ }^{(18)}$, and conduct interventions ${ }^{(21,29)}$.

In this context, the advocate for health competency shows its importance. Studies demonstrate that nurses are specially suited for raising awareness and exerting influence over issues such as excessive health spending and the defense of home care for older adults in detriment to outpatient care. The identification of this competency is rather important for nursing work. The practice of advocacy garnishes the attention of leaders, increasing the visibility of health promotion efforts ${ }^{(30)}$.
Communication is yet another vital health professional competency. Communicating effectively with older people is a true challenge, considering that this population may present cognitive and sensory difficulties. Strategies for verbal communication and active listening are, therefore, of significant importance. Studies with older people show that communication is necessary for training, use of instruments and application of theories. Researches highlight interventions focused on improving older people's communication with health professionals, as well as their access to social networks ${ }^{(19-20)}$.

Information technologies are important tools for the competency of communication. The studied researches identified technological communication resources, such as computer and telephone. The latter is the most used in intervention therapies targeting this population ${ }^{(16,18,20)}$.

In addition, health care requires every professional to design a care plan regarding diagnosis, planning and implementation. In this sense, the assessment competency enables the prioritization of the population's health needs. Examples of this practice are in $(18,22,28)$, which performed adjustments to the urination schedule based on the review of bladder diaries of older people and the identification of their health needs.

It is understood that a successful intervention is premised on a planning based on constant assessment. The studies demonstrate that projects were directed to older people's care and their families only after the assessment of specific recommendations ${ }^{(17-19,23,29)}$. Therefore, effective implementation requires good planning. This competency was clearly elucidated in the interventions.

At the end of a research, it is important to assess the impact and effectiveness of implemented actions. This concern was observed in all studies, since the sample consisted of clinical trials. Standing out, there were studies in which subjects were reassessed at the end of treatment, and the caregiver received a written summary of long-term recommendations ${ }^{(20-21,23)}$. Furthermore, the ability to publish studies' main results can in and of itself be considered an element of the assessment competency.

Most researches were carried out in foreign countries. Finally, because they had a clinical trial design, the effectiveness of their results could be directly ascertained.

\section{Study limitations}

The number of databases employed in the search was somewhat limited. By extending the search to other databases, more intervention studies with older people could have been included in this analysis.

\section{Contributions to the field of nursing}

Treatments used by nurses, as described in the analyzed studies, were beneficial to the homebound older population, confirming that interventions based on competencies for health promotion are not only present, but also produce an effective and high-quality care practice.

\section{CONCLUSION}

This review analyzed nine articles on nursing health promotion competencies targeting homebound older people. According to 
the obtained data, nurses foster several competencies, such as: health education, developing strategies for frailty recovery, promoting empowerment, establishing partnerships, and achieving change. All health promotion competencies were identified in the publications. "Communication" and "Evaluation and Research" were the most evidenced ones.

\section{REFERENCES}

1. Ribeiro O, Pinto C. Characteristics of a person who is dependent on self-care: a population based study in a region in the North of Portugal. Rev Port Saude Publica [Internet]. 2014 [cited 2017 Dec 1];32(1):27-36. Available from: https://doi.org/10.1016/j.rpsp.2013.07.001

2. Küchemann BA. Envelhecimento populacional, cuidado e cidadania: velhos dilemas e novos desafios. Soc Estado [Internet]. 2012 [cited 2017 Dec 10];27(1):165-80. Available from: http://dx.doi.org/10.1590/S0102-69922012000100010

3. Cruz DT, Caetano VC, Leite ICG. Envelhecimento populacional e bases legais da atenção à saúde do idoso. Cad Saude Coletiva [Internet]. 2010 [cited 2017 Dec 10];18(4):500-8. Available from: http://www.cadernos.iesc.ufrj.br/cadernos/images/csc/2010_4/artigos/CSC_ v18n4_500-508.pdf

4. Gottlieb MGV, Schwanke CHA, Gomes I, Cruz IBM. Longevity and aging in Rio Grande do Sul state: a hystorical, ethnic and morbimortality profile of elderly people. Rev Bras Geriatr Gerontol [Internet]. 2011 [cited 2017 Dec 8];14(2):365-80. Available from: http://dx.doi. org/10.1590/S1809-98232011000200016

5. Myrrha LJD, Siviero PCL, Wajnman S, Turra CM. The use of growth rates by age to identify the main stages of the demographic transition in Brazil. Rev Bras Estud Popul [Internet]. 2014 [cited 2017 Dec 1];31(2):259-75. Available from: http://dx.doi.org/10.1590/ S0102-30982014000200002

6. Instituto Brasileiro de Geografia e Estatística-IBGE. Primeiros resultados definitivos do Censo de 2010: população do Brasil é de 190.755 .799 pessoas. IBGE [Internet]. 2011 Apr 29 [cited 2017 Dec 1]. Available from: https://censo2010.ibge.gov.br/noticias-censo.html?view=noticia\&id =3\&idnoticia=1866\&busca=1\&t=primeiros-resultados-definitivos-censo-2010-populacao-brasil-190-755-799-pessoas

7. Ministério de Saúde (BR). Portaria n 2528, de 19 de outubro de 2006. Diário Oficial da União [Internet]. 2006 Oct 10 [cited 2017 Dec 1]1:142. Available from: http://bvsms.saude.gov.br/bvs/saudelegis/gm/2006/prt2528_19_10_2006.html

8. Mendes ECN, Pinto AS, Massaia E, Silva MPM. Intersubject care towards the health of the elderly: building knowledge about the healthy aging. Rev Conhecimento Online [Internet]. 2014 [cited 2017 Dec 1];6(1):1-11. Available from: https://periodicos.feevale.br/seer/index.php/ revistaconhecimentoonline/article/view/205

9. Brito MCC, Freitas CASL, Mesquita KO, Lima GK. Aging population and the challenges for public health: review of scientific production. Rev Kairós [Internet]. 2013 [cited 2017 Dec 8];16(2):161-78. Available from: http://pesquisa.bvs.br/brasil/resource/pt/lil-768818

10. Cestari VRF, Florêncio RS, Moreira TMM, Pessoa VLMP, Barbosa IV, Lima FET, et al. Nursing competencies in promoting the health of individuals with chronic diseases. Rev Bras Enferm [Internet]. 2016 [cited 2017 Dec 13];69(6):1129-37. Available from: http://dx.doi. org/10.1590/0034-7167-2016-0312

11. Barry MM, Battel-Kirk B, Davison H, Dempsey C, Parish R, Schipperen M, et al. The CompHP Core Competencies Framework for Health Promotion Handbook [Internet]. Paris: International Union for Health Promotion and Education; 2012 [cited 2017 Dec 3]. Available from: https://www.fundadeps.org/recursos/documentos/450/CompHP_Project_Handbooks.pdf

12. Pinheiro DGM, Scabar TG, Maeda ST, Fracolli LA, Pelicioni MCF, Chiesa AM. Health promotion competencies: challenges of formation. Saúde Soc [Internet]. 2015 [cited 2017 Dec 3];24(1):180-8. Available from: http://www.scielo.br/pdf/sausoc/v24n1/0104-1290-sausoc-24-1-0180.pdf

13. Galvão TF, Pereira MG. Systematic reviews of the literature: steps for preparation. Epidemiol Serv Saúde [Internet]. 2014 [cited 2017 Dec 15];23(1):183-4. Available from: http://scielo.iec.gov.br/pdf/ess/v23n1/v23n1a18.pdf

14. Pereira MG, Galvão TF. Data extraction, quality assessment and synthesis of results for systematic reviews. Epidemiol Serv Saúde [Internet]. 2014 [cited 2017 Dec 15];23(3):577-8. Available from: http://scielo.iec.gov.br/pdf/ess/v23n3/Resumos\%20_es/Serie\%20(1).pdf

15. Tuntland H, Aaslund MK, Espehaug B, Førland O, Kjeken I. Reablement in community-dwelling older adults: a randomised controlled trial. BMC Geriatr. 2015 [cited 2017 Nov 8];15:145. Available from: https://doi.org/10.1186/s12877-015-0142-9

16. Gellis ZD, Kenaley BL, Have TT. Integrated telehealth care for chronic illness and depression in geriatric home care patients: the Integrated Telehealth Education and Activation of Mood (I-TEAM) study. J Am Geriatr Soc. [Internet]. 2014 [cited 2017 Nov 8];62(5):889-95. Available from: https://doi.org/10.1111/jgs.12776

17. Kono A, Kanaya Y, Tsumura C, Rubenstein LZ. Effects of preventive home visits on health care costs for ambulatory frail elders: a randomized controlled trial. Aging Clin Exp Res [Internet]. 2013 [cited 2017 Nov 8];25(5):575-81. Available from: https://doi.org/10.1007/ s40520-013-0128-4

18. Gellis ZD, Kenaley B, McGinty J, Bardelli E, Davitt J, Have TT. Outcomes of a telehealth intervention for homebound older adults with heart or chronic respiratory failure: a randomized controlled trial. Gerontologist [Internet]. 2012 [cited 2017 Nov 8];52(4):541-52. Available from: https://doi.org/10.1093/geront/gnr134

19. Shearer NBC, Fleury JD, Belyea M. Randomized control trial of the Health Empowerment Intervention: feasibility and impact. Nurs Res [Internet]. 2010 [cited 2017 Nov 8];59(3):203-11. Available from: https://doi.org/10.1097/NNR.0b013e3181dbbd4a 
20. Boyd CM, Shadmi E, Conwell LJ, Griswold M, Leff B, Brager R, et al. A pilot test of the effect of guided care on the quality of primary care experiences for multimorbid older adults. J Gen Intern Med [Internet]. 2008 [cited 2017 Nov 8];23(5):536-42. Available from: https://doi. org/10.1007/s11606-008-0529-9

21. Vass M, Avlund K, Siersma V, Hendriksen C. A feasible model for prevention of functional decline in older home - dwelling people - the GP role. A municipality-randomized intervention trial. Fam Pract [Internet]. 2009 [cited 2017 Nov 8];26(1):56-64. Available from: https://doi. org/10.1093/fampra/cmn094

22. Engberg S, Sereika SM, McDowell BJ, Weber E, Brodak I. Effectiveness of prompted voiding in treating urinary incontinence in cognitively impaired homebound older adults. J Wound Ostomy Continence Nurs [Internet]. 2002 [cited 2017 Nov 8];29(5):252-65. Available from: https://doi.org/10.1067/mjw.2002.127207

23. McDowell BJ, Engberg S, Sereika S, Donovan N, Jubeck ME, Weber E, et al. Effectiveness of behavioral therapy to treat incontinence in homebound older adults. J Am Geriatr Soc [Internet]. 1999 [cited 2017 Nov 8];47(3):309-18. Available from: https://doi. org/10.1111/j.1532-5415.1999.tb02994.x

24. Ministério da Saúde (BR). Secretaria de Atenção à Saúde. Departamento de Atenção Básica. Caderno de atenção domiciliar. Brasília, DF: Ministério da Saúde; 2013.

25. Witt RR, Roos MO, Carvalho NM, Silva AM, Rodrigues CDS, Santos MT. Professional competencies in primary health care for attending to older adults. Rev Esc Enferm USP [Internet]. 2014 [cited 2017 Dec 12];48(6):1020-5. Available from: http://dx.doi.org/10.1590/ S0080-623420140000700009

26. Irvine F. Examining the correspondence of theoretical and real interpretations of health promotion. J Clin Nurs [Internet]. 2007 [cited 2017 Dec 18];16(3):593-602. Available from: http://dx.doi.org/10.1111/j.1365-2702.2005.01539.x

27. Whitehead D. Health promotion and health education: advancing the concepts. J Adv Nurs [Internet]. 2004 [cited 2017 Dec 18];47(3):31120. Available from: http://dx.doi.org/10.1111/j.1365-2648.2004.03095.x

28. Allen KR, Hazelett SE, Radwany S, Ertle D, Fosnight SM, Moore PS. The Promoting Effective Advance Care for Elders (PEACE) randomized pilot study: theoretical framework and study design. Popul Health Manag [Internet]. 2012 [cited 2017 Nov 8];15(2):71-7. Available from: http:// dx.doi.org/10.1089/pop.2011.0004

29. Melis RJF, Eijken MIJ, Boon ME, Rikkert MGMO, Achterberg T. Process evaluation of a trial evaluating a multidisciplinary nurse-led home visiting programme for vulnerable older people. Disabil Rehabil [Internet]. 2010 [cited 2017 Nov 8];32(11):937-46. Available from: http:// dx.doi.org/10.3109/09638280903381006

30. Lee CB, Chen MS, Powell MJ, Chu CMY. Organisational change to health promoting hospitals: a review of the literature. Springer Sci Rev [Internet]. 2013 [cited 2017 Nov 15];1(1-2):13-23. Available from: https://doi.org/10.1007/s40362-013-0006-7 